\title{
Connecting Users with Special Collections
}

\section{Describing Rare Books without a Rare Book Cataloger}

By Christa Strickler, Wheaton College (Illinois)

\begin{abstract}
Buswell Library at Wheaton College in Illinois faced a cataloging backlog of thousands of rare materials focusing on American and British Protestant evangelism and missions. Cataloging staff used creative thinking to solve challenges such as lack of staff time and expertise. We collaborated with special collections staff to determine specific user needs, then used our knowledge of metadata practices to meet those needs. Many complicated items appeared in the workflow, but we found creative ways to make them accessible. To communicate the project to the rest of the library, we presented at a staff meeting, explaining the types of materials cataloged and sharing tips for searching for them. The project significantly increased the amount of special collections items cataloged annually and allowed us to connect faculty and students with our valuable research materials.
\end{abstract}

\section{START WITH AN OPPORTUNITY}

Buswell Memorial Library at Wheaton College in Illinois faced an exciting opportunity when the Billy Graham Center (BGC) Library and the BGC Museum transferred thousands of holdings to our special collections. These holdings comprised a vast array of materials, including artwork, pamphlets, and rare books. The focus of the bulk of the collections was United States and British Protestant evangelism and missions, with related church history materials. We received several sermons preached to missionary societies, translations of the Bible into languages such as Sinhalese, and pamphlets celebrating the virtues of temperance. 


\section{OVERCOME CHALLENGES WITH CREATIVE THINKING}

However, opportunities such as this often come with challenges, many of which require creative thinking to overcome.

One common challenge is the lack of staff time. When I arrived at Wheaton College in 2014, these materials still hadn't been cataloged, even though the BGC had owned the materials for decades. The day I started, the monographs cataloging staff included me, who is responsible for all the original cataloging, and two associates for handling the copy cataloging. Within two weeks, one associate left, and the position was not replaced. I needed to find time to tackle the rare materials collection with only two people and numerous other priorities.

Our solution to this problem was to reallocate resources. We add approximately 8,700 print monographs per year with only one copy cataloger. Before I arrived, the library began moving to shelf-ready cataloging through GOBI, formerly known as YBP. This freed up staff time for other projects. Cataloging staff were also spending a lot of unnecessary time on inefficient, outdated practices, so I removed unnecessary busy work and streamlined tasks by creating batch editing processes with MarcEdit. This freed up enough time that we were ready to begin tackling the rare books by the summer of 2017 .

We also lacked expertise. I came to Wheaton from a small Assemblies of God college and hadn't cataloged anything older than Pentecostal sermons from the 1930s. When we started the project, my copy cataloger had been at Wheaton less than a year and had no previous cataloging experience.

One solution to lack of expertise is to find low-cost resources. You can find inexpensive print materials, such as The Dictionary of the Book: a Glossary for Book Collectors, Booksellers, Librarians, and Others, by Sidney E. Berger. It includes mid-length entries on genres and formats. When I came across items that were unusual to me, such as a salesman's dummy for a biography of the evangelist Billy Sunday, I could flip through the pages of the dictionary and sometimes find a name for the item in my hand. You can also find free resources online. We found the Beinecke Rare Book \& Manuscript Library's Rare Book Cataloging documentation particularly helpful. At the end of this paper, I've included a bibliography of resources that we found helpful. Local experts are another valuable resource. Wheaton College is privileged to have 
the Marion E. Wade Center, a special library preserving materials on British authors such as C. S. Lewis, J. R. R. Tolkien, and Dorothy Sayers. While their focus is on twentieth-century materials, they had been doing special cataloging practices for years, so we met with their cataloger to get a sense of some of their policies and user needs.

Another solution to the lack of expertise is to omit what you don't know. You can always return to your catalog records to improve them when you gain more knowledge. The standard set of cataloging rules for rare books is Descriptive Cataloging of Rare Materials:Books, commonly known as DCRM(B). We weren't confident about following DCRM(B) rules without having someone check our work, so we used RDA, the cataloging rules that we follow for our newer materials. Another aspect we omitted was the collational formula, which is a notation system for describing the signatures in an "ideal copy" of a book. A collational formula might look something like this: $[A]^{4} B-C^{4} D^{2} E-G^{4}$. Rare book catalogers describe the "ideal copy" of a book, then make extensive notations about how the copy in hand differs. We didn't know how to do this and didn't have the confidence to attempt it without training, so we left it out. We also omitted detailed descriptions of physical characteristics, such as book bindings, clasps, and paper type. We didn't know the difference between a Cosway binding and a cottage style binding, or between cocoa marbled papers and curl marbled papers, so we didn't attempt to guess.

\section{KNOW YOUR USERS' NEEDS}

An important thing to keep in mind while tackling a rare book project is to know your users' needs. This may seem obvious, but it was a crucial component of our project.

One problem that we faced was that we didn't know our users' needs. We do our monograph cataloging work in the main library building, which is on the other side of campus from our special collections, so we rarely interact with special collections users. To alleviate this, we collaborated with special collections staff, meeting with them a few times to discuss users' needs and how we might fulfill them with metadata. We pooled our knowledge of metadata standards and practices with the special collections staff's knowledge of user needs to create a strategy. 
One user need was acquisitions data. Books coming from the BGC Museum had accession numbers that special collections staff wanted to keep. We don't record accession numbers in our regular cataloging processes, so this was a new practice for us. Our solution was to use the 541 field (Immediate Source of Acquisition Note). We recorded the copy-specific information in $\$ 3$, the source of acquisition in $\$$ a, the accession number in $\$$ e, and our MARC institution code in $\$ 5$ :

- $5411 \backslash$ \$ SC-233 c. 1 †a BGC Museum; łe 92.9. \$5 IWW

Another user need was item-specific data. Traditional cataloging focuses on the manifestation level, while rare book cataloging often needs to describe materials at the item level, such as recording damage to a particular copy or recording provenance evidence of an item. Buswell Library is hoping to implement an automatic overlay project with OCLC in the future, automatically overlaying our records in Voyager with updated records from OCLC, so we needed to differentiate our item-specific data from the data found in the OCLC master record. Our solution had two parts: recording the unstructured data in the 590 field (Local Note) and using other fields for structured data, appending $\$ 5$ (Institution to Which Field Applies) with our MARC institutional code:

- $590 \backslash \ 3$ SC-233 c. 1 ta Extensive notes by Jim Elliot throughout item.

- $5411 \backslash \nmid 3$ SC-233 c. 1 †a BGC Museum; †e 92.9. †5 IWW

We do not put these fields in the OCLC master record because they only apply to our specific item. We've also created a bulk import rule in our ILS, instructing it to protect data of this type in an overlay to make sure that we don't lose it in our automatic overlay project.

A related user need was provenance data. Some records corresponded to materials with important former owners, and we wanted library users researching those people to find these items. For example, we cataloged a Bible owned by Redd Harper, a twentieth-century American evangelist, and a miniature book of poetry with a bookplate reading, "Library of Franklin D. Roosevelt." Our solution was to record this data in the 700 field (Added Entry-Personal Name) with a \$e (Relator Term) appended to explain the relationship: 
- $7001 \backslash$ ła Harper, Redd, $\neq$ 1903-1992, †e former owner. $\$ 5$ IWW

- $7001 \backslash \nmid a$ Roosevelt, Franklin D., łq (Franklin Delano), łd 18821945, †e associated name. $\$ 5$ IWW

We used different relator terms depending on the need. The evidence for Redd Harper's ownership of this copy of the Bible was clear, so we used the relator term "former owner" to indicate his relationship to the item. We weren't as confident in the provenance evidence for the book of poetry with Roosevelt's name in it, so we used the term "associated name" to indicate that he had an association with the item without claiming that he owned it.

Another related need was for annotation data. When important people have written in a particular copy, we want to connect the bibliographic record to those people. For example, we cataloged a copy of the Bible that had extensive cover and marginal notes written by former owner Jim Elliot, a missionary to Ecuador. Our solution was an expanded version of the one for provenance data. We recorded Elliot's name in a 700 field (Added Entry-Personal Name), with relator terms for "annotator" and "former owner," added a 590 field (Local Note) with a note about the extent of the annotations, and included a 655 field (Genre/Form):

- $590 \backslash \nmid 3$ SC-233 c. 1 ła Extensive notes by Jim Elliot throughout item.

- $655 \backslash 7 \$ 3$ SC-233 c. 1 ta Annotations. $\$ 2$ rbprov $\$ 5$ IWW

- $7001 \backslash \nmid 3$ SC-233 c. $1 \nmid a$ Elliot, Jim, łd 1927-1956, łe annotator, fe former owner. $\$ 5$ IWW

The "Annotations" term came from the Rare Books and Manuscripts Section (RBMS) provenance vocabularies. RBMS is a division of the Association of College \& Research Libraries, and they've created vocabularies for categories such as bindings, genres, and provenance.

We cataloged over one hundred miniature books for this project, and our special collections librarian wanted a way to find them all without separating them into their own physical location. Our solution for this was to add a 655 field (Genre/Form) with a term from the RBMS Printing \& Publishing Terms vocabulary:

- $655 \backslash 7$ †a Miniature books (Printing). $\$ 2$ rbpri 
Items from the BGC Museum often had an emphasis on the artistic value. We cataloged illustrated editions of the Bible and Pilgrim's Progress, along with some beautifully illustrated unique manuscripts, and we wanted these to be findable by their artistic value and not become lost among all the other Bibles and copies of Pilgrim's Progress that we owned. Our solution was yet again to add a 655 field (Genre/Form) with a term from the RBMS Genre Terms vocabulary:

- $655 \backslash 7$ †a Illustrated works. $¥ 2$ rbgenr

\section{DO YOUR BEST WITH THE TRICKY ITEMS}

Tricky items are an inevitable part of rare book cataloging. Following are some examples of tricky items we encountered and how we handled them.

One challenge we faced was materials in foreign languages. We received Bibles in Chinese, Burmese, and Sinhalese, along with nineteenth-century German books in Fraktur script, but our foreign language expertise was in French and Spanish. For items with Roman scripts, we used Google Translate, which we installed on an iPad so we could take pictures of the text to avoid transcription. The original language appears transcribed on the screen along with the translation. It's not perfect, but it gave us enough of an idea to create subject headings. Items in non-Roman scripts, such as Chinese, Japanese, Burmese, and Arabic, we outsourced to Backstage Library Works. The records we received were of varying quality depending on the language, but they were good enough for a base record that I could edit to in-house cataloging standards.

Another challenge was a biography of George Whitefield: Life of the Rev. George Whitefield, by D. A. Harsha. The corresponding OCLC record looked in order except for a large discrepancy in the number of pages, so the copy cataloger passed it to me. We discovered that somebody had removed the spine of the original book to separate the pages, then inserted supplementary content throughout the volume and rebound it. Where the biography's text mentioned well-known people related to Whitefield's life, such as William Cowper or George I of England, portraits of these people, cut from other books, were inserted next to the text. Also included was a Harper's Weekly journal article about Whitefield's hometown of Newburyport, Massachusetts. My solution 
to this was to derive a new record for the original biography and include a 500 field (General Note) attempting to explain the nature of the items, a 501 field (With Note) as an unstructured note about the journal article, and a 774 field (Constituent Unit Entry) as a structured way to link to the original journal article:

- $500 \backslash \backslash$ fa Interspersed with plates not part of the original publication. Images of people and places mentioned in the text are bound next to the page where mentioned.

- $501 \backslash$ fa With: Newburyport and its neighborhood / by Harriet Prescott Spofford. New York, Harper \& Bros., 1875.

- 77408 i Container of (manifestation): Elizabeth Prescott, 1835-1921. Newburyport and its neighborhood. łd New York, Harper \& Bros., 1875 tw (OCoLC)20608439

Sammelbände, or bound-withs, were another common occurrence in our workflow, particularly volumes of separately published tracts or sermons bound together. We decided to create analytic descriptions for each item to allow the best possible access for our library users. We then use our ILS's "bound with" function to link them to one barcode. We also include a 501 field (With Note) in each record to indicate the item was bound with others:

- $501 \backslash \downarrow$ ta Bound with miscellaneous sermons by C. H. Spurgeon. $\ddagger 5 \mathrm{IWW}$

We also had difficulties with some items that we did not have the expertise to identify. One miniature book, only two centimeters tall, had a picture of a saint on every page, and a title page with the words "Fevrier 28 jours" and no other identifying information. We worried that only including that nondescript title would not be enough for users to identify the item without information about illustrator or time period. I posted some pictures of the item on the Troublesome Catalogers and Magical Metadata Fairies Facebook group page, and their expertise combined with detailed Google searching resulted in enough information to create a more helpful record:

- $1000 \backslash$ †a Michel, łc (Fils ainé), łe artist.

- 24510 †a [Calendrier de tous les saints]. $\neq p$ Fevrier 28 jours / †c [illustré par Michel fins ainé ; gravé par Lechard]. 
- $264 \backslash 1$ †a [France] : [publisher not identified], łc [1815?]

- $300 \backslash \backslash$;a 300 unnumbered pages :

- $500 \backslash \backslash$ ta Originally part of a 12 -volume set.

- $500 \backslash \backslash$ ta Engraving of a saint for each day of the month.

- $650 \backslash 0$ ta Christian saints łx Calendar.

- $655 \backslash 7$ ta Devotional calendars. $\$ 2$ rbgenr

- $655 \backslash 7$ ła Miniature books (Printing). $\$ 2$ rbpri

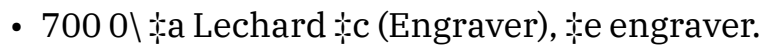

One manuscript we cataloged was in a language and script that we could not identify, but somebody had included slips of paper describing the item, so we did our best to create a record from that information:

- $041 \backslash$ ła amh fa gez

- 24510 ta [Bible portions in Amharic].

- $264 \backslash 0$;Ethiopia?] : [producer not identified], $\$ c$ [not before the middle of the 15 th century]

- $500 \backslash \backslash$ fa Note inserted in volume: "A portion of the Scriptures in Amharic from Ethiopia. The pages are made out of animal skins. One column is Geez."

- $500 \backslash \backslash$ Note inserted in volume: "Detailed description of the passion of the Christ. Few pages about Trinity. Description of Mary. All in Amharic except quotations from the Scripture and the last seven page that are in Geez (Ethiopic). The date could not be earlier than the middle of 15 th century because of the mention of King Zera Yaqob."

We also cataloged the unpublished illustrations of a poem in manuscript form. The solution to that challenge was to derive a record from the published version and make the changes applicable to the manuscript. We recorded notes on its format and created a 787 field linking it to the published version:

- $1000 \backslash$ ła Cleaveland, Elizabeth H. Jocelyn, $\neq q$ (Elizabeth Hannah Jocelyn), †d 1824-1911, łe author.

- 24510 fa No sect in heaven / $\$ \mathrm{c}$ illustrated and engrossed by F. Schuyler Mathews. 
- $500 \backslash$ fa The drawings by F. Schuyler Mathews, glued to cards bound by ribbon, and marked for final placement in the published volume. Some pencil lines for text placement still visible.

- 78708 łi illustrations for (expression): fa Cleaveland, Elizabeth H. Jocelyn, (Elizabeth Hannah Jocelyn), 1824-1911 $\$$ s No sects in heaven. ft No sect in heaven. $\neq d$ Boston : L. Prang \& Co., (c1891 tw (DLC) $21019367 \mathrm{tw}$ (OCoLC)10646608

\section{INFORM YOUR COLLEAGUES}

Though we were doing some great work, many of our colleagues were not aware of the project or the work required for it, so I wanted to raise awareness of our work and show our colleagues how to access the cataloged materials.

I did this primarily through a presentation at one of our monthly staff meetings. I talked about collection strengths and how those affect our cataloging policies. I then gave examples of some of those collection strengths, such as temperance literature, pro- and anti-slavery literature, and materials on the First Great Awakening. I also showed examples of the different genre terms they could use to find the materials, such as miniature books, antislavery literature, or hymn texts. After the meeting, I sent a follow-up email to the staff to explain the difference between searching for these things in our discovery layer (WorldCat Discovery) and our catalog (VuFind). I explained that much of the item-specific information would not display or index in the discovery layer, so they would need to use the catalog if they needed to use that metadata for searching.

\section{REVEL IN THE REWARDS}

The most tangible reward was the dramatic increase in Special Collections cataloging. We started the project in 2017, and the amount cataloged has helped generate interest from the rest of the library:

Another reward has been an

\begin{tabular}{lc}
\multicolumn{1}{c}{ YEAR } & ITEMS CATALOGUED \\
\hline 2014 & 177 \\
\hline 2015 & 144 \\
\hline 2016 & 82 \\
\hline 2017 & 896 \\
\hline 2018 & 2311 \\
\hline
\end{tabular}

FIVE-YEAR COMPARISON of Special Collections cataloging 
increased ability to connect faculty with research materials. One of our faculty members is interested in the Puritans, so I would notify him whenever we cataloged relevant items, such as a book by the Puritan theologian Richard Baxter, published in 1680.

We have also been able to connect students with hard-to-find items. One day I was at the reference desk helping a student who was writing about Christian publishing in China during the early twentieth century. I was able to find some recently cataloged annual reports from the Society for the Diffusion of Christian \& General Knowledge Among the Chinese, published at the time she was studying. By far the greatest reward for me has been to play a role in preserving history. When I hold a 1558 work by the Lutheran Reformer Philipp Melanchthon in my hands, I'm overwhelmed by the great privilege I have in preserving the heritage of my faith and making it more accessible to others.

\section{ANNOTATED BIBLIOGRAPHY}

“Advance Reading Lists." Rare Book School (blog). Accessed May 17, 2018. https://rarebookschool.org/course-descriptions/reading/.

Includes reading lists for Rare Book School courses such as The Bible and Histories of Reading, Rare Book Cataloging, and Advanced Descriptive Bibliography.

Beinecke Rare Book \& Manuscript Library. "Beinecke Cataloging Manual.” Accessed June 12, 2018. http://beinecke1.library.yale. edu/info/bookcataloging/home.htm.

Cataloging procedures from the rare book catalogers at Yale University.

Berger, Sidney E. The Dictionary of the Book: A Glossary for Book Collectors, Booksellers, Librarians, and Others. Lanham, Maryland: Rowman \& Littlefield, 2016.

Includes medium-length definitions of rare book terms suitable for a non-specialist audience. Great for helping to identify unfamiliar genres and formats.

British and Foreign Bible Society., T. H. Darlow, and H. F. Moule. Historical Catalogue of the Printed Editions of Holy Scripture in the 
Library of the British and Foreign Bible Society. Historical Catalogue of Printed Bibles. London: Bible House, 1903. https://catalog. hathitrust.org/Record $\backslash 001179750$.

We cataloged some early Bibles, and this book helped us provide more detailed descriptions of some of them. Freely available online in HathiTrust.

“British Book Trade Index.” Accessed June 12, 2018. http://bbti. bodleian.ox.ac.uk/.

Contains biographical information on people in the English and Welsh book trades through 1851. Good for looking up details on publishers, bookbinders, engravers, etc.

Carter, John, and Nicolas Barker. ABCfor Book Collectors. Eighth ed. New Castle, Delaware: Oak Knoll Press, 2004. https://www.ilab. org/articles/john-carter-abc-book-collectors.

A helpful glossary of terms. Not the newest edition, but this one is available for free online.

Folger Shakespeare Library. "Category:Cataloging - Folgerpedia.” Folgerpedia. Accessed June 11, 2018. https://folgerpedia.folger. edu/Category:Cataloging.

Cataloging procedures from rare book specialists at the Folger Shakespeare Library.

Gaskell, Philip. A New Introduction to Bibliography. [Corr. ed.].

Winchester, UK: St. Paul's Bibliographies, 1995.

We didn't use this for our work, but we kept encountering it as a standard text in the field.

Rare Books and Manuscripts Section. "Descriptive Cataloging of Rare Materials.” RBMS - Rare Books \& Manuscripts Section, September 25, 2014. http://rbms.info/dcrm/.

Includes links to standard cataloging manuals for rare books, manuscripts, maps, and more.

—. "RBMS Controlled Vocabularies: Controlled Vocabularies for Use in Rare Book and Special Collections Cataloging." RBMS - Rare Books \& Manuscripts Section. Accessed June 12, 2018. http://rbms.info/vocabularies/index.shtml?PHPSESSID=8ba066 bf9bde0d8ba910c05e80bfdcd3. 
Includes binding terms, genre terms, paper terms, printing \& publishing evidence, provenance evidence, type evidence, and relationship designators. A must-see for terms to include in 655 fields. Has some overlap with LC vocabularies and RDA relationship designators.

Wolfe, S. J. "Dating American Tract Society Publications Through 1876.” Text. American Antiquarian Society, November 12, 2013. http:// www.americanantiquarian.org/node/6693.

We cataloged several undated tracts from the American Tract Society, and this web page was essential for helping us supply publication dates. 